\title{
金属粉末射出成形法による焼結合金工具鋼の組織および機械的性質に及ぼす粉末特性の影響
}

\author{
中山 英樹的 1 , 京極 秀樹的 2 , 小松眞一郎的 2 \\ ロ1キングインベスト(㑣)，テ720-0004 福山市御幸町中津原 1812 . \\ 丸2 近畿大学工学部機械システム工学科, $\overline{\mathbf{T}} 739-2116$ 東広島市高屋うめの辺 1.
}

\section{Effect of Powder Characteristics on The Microstructures and Mechanical Properties of Sintered Alloy Tool Steel Compacts by Metal Injection Molding}

\author{
Hideki Nakayama ${ }^{\text {1 } 1}$, Hideki Kyogoku ${ }^{\text {स2 }}$ and Shinichiro Komatsu \\ ${ }^{4}$ King Invest Co., Ltd., 1812 Nakatsuhara Miyuki-cho, Fukuyama 720-0004. \\ 2 2 Department of Mechanical Systems Engineering, School of Engineering, Kinki University, 1 Takayaumenobe, Higashihiroshima $739-2116$.
}

Received August 7, 2000

\section{SYNOPSIS}

The effects of powder characteristics on the microstructures and mechanical properties of sintered alloy tool steel (SKD11) compacts by metal injection molding were investigated. A gas-atomized (GA) and a water-atomized (WA) alloy tool steel powders and a polyamide binder were used. They were mixed well and injected into metallic molds for transverse test specimens. These injection-molded specimens were debound at $593 \mathrm{~K}$ in air and then were sintered at various temperatures between $1473 \mathrm{~K}$ and $1483 \mathrm{~K}$ in vacuum. These sintered compacts were heated at $1293 \mathrm{~K}$ and quenched, and then were tempered at various temperatures between $453 \mathrm{~K}$ and $803 \mathrm{~K}$. The densification of the GA powder compact was fairly superior to that of the WA powder compacts. Consequently, the mechanical properties of the sintered GA powder compacts were superior to those of the sintered WA powder compacts. The mechanical properties equivalent to those of the wrought alloy tool steel could be fabricated successfully by controlling the sintering and heat-treatment conditions precisely.

KEY WORDS

Metal Injection Molding, Alloy Tool Steel, Powder Characteristics, Microstructure, Mechanical Properties

\section{1 緒言}

金属粉末射出成形法 (MIM)は，金属粉末とバインダを混 合・混練し，金型に射出成形を行い，バインダを除去し焼結 するプロセスである．このプロセスでは 3 次元的な複雑形状 の部品が精度良く製造できるという利点を有しており，種々 の金属材料の成形加工に幅広く活用されてきている. 合金工 具鋼は熱処理を施すことにより優れた硬さを得ることができ る鋼種として，切削工具材や金型材などに幅広く適用されて いる，合金工具鋼は難削材であり，鋳造材では結晶粒界に層 状炭化物が形成し易く，機械的性質が劣化するという欠点が ある.このような難加工材の合金工具鋼をニア・ネット・シエ イプで加エできれば，一層の応用が期待できる. MIMによる 高速度工具鋼の作製条件に関するいくつかの報告 $\left.{ }^{1-4}\right)$ はある が，合金工具鋼に関する報告は少なく，合金工具鋼としての 最適な特性を得るためには焼結温度や炭素量の精密な制御が 指摘されている 械的性質に及ぼす粉末特性の影響について検討しており，ガ
スアトマイズおよび水アトマイズ粉末の違いにより組織中の 炭化物の形状が大きく巽なり，これが機械的性質に大きな影 響を及ぼすと報告している.このように，一般に粉末特性は 焼結体の密度や機械的性䁈に大きな影響を及ぼすため, MIM による合金工具鋼においても，この点を十分に検討しておく ことは重要である.

本研究では，合金工具鋼の中でもよく用いられる高炭素， 高クロム材のSKD11について水アトマイズ粉末とガスアトマ イス粉末を用いて，両者の粉末特性が焼結体の密度と組織さ らには機械的性質に及ぼす影響について検討をした。

\section{2 試料および実験方法}

原料粉末には SKD11 の水アトマイズ(WA)粉末およびガス アトマイズ(GA)粉末を用いた. Table 1に水アトマイズ粉末と ガスアトマイス粉末の化学組成, Table 2 に両粉末の特性を示 す.酸素含有量は水アトマイズ粉末では 0.24 mass\%であり，

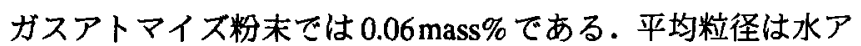


トマイズ粉末では $10 \mu \mathrm{m}$, ガスアトマイズ粉末では $11.36 \mu \mathrm{m}$ ある. また，これらの粉末の SEM 写真を Fig.1に示す.これ らの粉末をポリアミド系バインダと混合・混練し，抗折試験 片用金型に射出成形機を用い成形した。それらの成形体を大 気中で593Kに加熱して脱バインダを行った後, 真空焼結炉を 用い真空中で焼結温度 $1473 \mathrm{~K}, 1478 \mathrm{~K}$ および $1483 \mathrm{~K} て ゙$ 焼結を 行った. 熱処理は，組織を均一化するために温度 $1173 \mathrm{~K} て ゙$ 保 持時間 $10.8 \mathrm{ks}$ で炉冷により焼なまし処理を行い，温度 $1293 \mathrm{~K}$ から $\mathrm{N}_{2}$ ガスにより強制冷却することにより焼入れ処理を行っ た. その後, 温度 $453 \mathrm{~K}, 543 \mathrm{~K}$ およひ $803 \mathrm{~K} て ゙$ 焼もどし処理後 空冷を行った.

焼結体の密度はアルキメデス法により測定した。焼結体の 組織は腐食後に金属顕微鏡により観察した. 抗折試験はイン ストロン試験機を用い, クロスヘッド速度を $8.33 \times 10^{-6} \mathrm{~m} / \mathrm{s}$ で 試験した．硬さはロックウエル硬度計を用い，Cスケールに より測定した。

\section{3 実験結果および考察}

3.1 作製条件の検討

合金工具鋼の密度および組織は焼結温度に対して非常に敏 感であるため, 焼結温度が焼結体の密度および組織に及ぼす 影響について検討しておくことが重要である. 焼結温度に対 する焼結体の密度変化を Fig.2に示す. 水アトマイズ粉末焼結 体においてもガスアトマイズ粉末焼結体においても，焼結温 度の上昇に伴い密度は高くなっている. ガスアトマイズ粉末 焼結体では焼結温度 $1473 \mathrm{~K}$ から 1478Kの間で水アトマイズ粉 末焼結体の密度より高い值を示しているが, 焼結温度 $1483 \mathrm{~K}$ では両粉末の焼結体の密度はほぼ同等の值となっている.こ

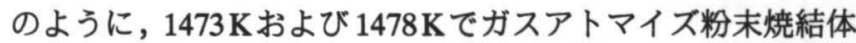

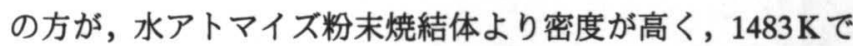
ほぼ同じ密度を示すのは，前者の温度域では固相焼結が支配 的であるのに対して, 後者の温度では液相焼結が支配的であ るためと考えられる.すなわち，固相焼結では，一般的に言 われるように，また粉末射出成形の場合にも三浦ら ${ }^{3)}$, 著者らの

Table 1 Chemical compositions of gas-atomized and wateratomized alloy tool steel powders.

\begin{tabular}{|c|c|c|c|c|c|c|c|c|}
\hline \multirow{2}{*}{ Powder } & \multicolumn{7}{|c|}{ Chemical composition(mass\%) } \\
\cline { 2 - 9 } & $\mathrm{C}$ & $\mathrm{Si}$ & $\mathrm{Mn}$ & $\mathrm{Cr}$ & $\mathrm{Mo}$ & $\mathrm{Co}$ & $\mathrm{V}$ & $\mathrm{O}$ \\
\hline GA & 1.58 & 0.09 & 0.29 & 11.6 & 0.90 & 0.04 & 0.70 & 0.06 \\
\hline WA & 1.50 & 0.30 & 0.55 & 12.1 & 0.98 & - & 0.45 & 0.24 \\
\hline
\end{tabular}

Table 2 Characteristics of gas-atomized and water-atomized alloy tool steel powders.

\begin{tabular}{|c|c|c|c|c|c|c|}
\hline \multirow[b]{2}{*}{ Powder } & \multicolumn{4}{|c|}{ Screen analysis(\%) } & \multirow{2}{*}{$\begin{array}{c}\text { Mean } \\
\text { particle } \\
\text { size } \\
(\mu \mathrm{m})\end{array}$} & \multirow{2}{*}{$\begin{array}{c}\text { Tap } \\
\text { density } \\
\left(\mathrm{Mg} / \mathrm{m}^{3}\right)\end{array}$} \\
\hline & $\begin{array}{c}0 / 11 \\
(\mu \mathrm{m})\end{array}$ & $11 / 22$ & $22 / 31$ & $31 /$ & & \\
\hline GA & 48.1 & 45.5 & 6.4 & 0.0 & 11.36 & 4.51 \\
\hline WA & 55.2 & 30.2 & 9.6 & 5.0 & 10.00 & 3.66 \\
\hline
\end{tabular}

も報告しているように，タップ密度の高いガスアトマイズ粉 末の密度の方が高くなったものと考えられる.これに対して， $1483 \mathrm{~K}$ では液相焼結を伴い，両粉末の場合とも $7.7 \mathrm{Mg} / \mathrm{m}^{3}$ 程度 の高密度の焼結体を得ることができた．このように，本研究 では非常に高密度の焼結体を作製することができた.

ガスアトマイズ粉末を用いた焼結のみ，および焼なましを 施した焼結体の焼結温度別の組織をFig.3に示す. 焼結のみの ものではマトリックスにフェライト(白い部分)とパーライト (黒い部分) が現出しているのに対して, 焼なまし処理を施し たものではフェライトのみのマトリックスになっている. ま た，焼結のみおよび焼なましを施した焼結体の組織には 2 種 類の炭化物, すなわち結晶粒界に沿って角張った粗い炭化物 と均一に分布した微細な球状炭化物が観察される. 角張っ た粗い炭化物は $\mathrm{M}_{7} \mathrm{C}_{3}$ で, 微細な球形炭化物は $\mathrm{M}_{23} \mathrm{C}_{6}$ であると 考えられる ${ }^{7} . \mathrm{M}_{7} \mathrm{C}_{3}$ は共晶炭化物であるため，この形成は液 相の発生を示唆している. $\mathrm{M}_{7} \mathrm{C}_{3}$ 炭化物は焼結温度が高くなる に従い粗大化しているが, これらの炭化物は溶製材の炭化物 より小さい.ガスアトマイズおよび水アトマイズ粉末焼結体の 密度は液相の発生により,一層高くなると考えられ，焼結温

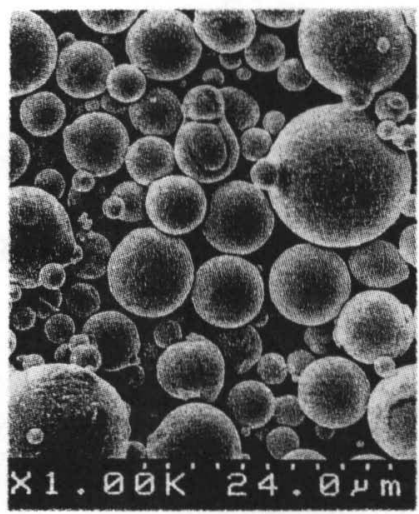

(a) GA powder

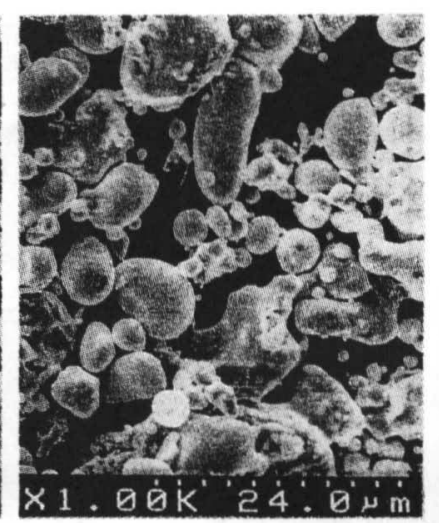

(b) WA powder
Fig.1 SEM images of gas-atomized and water-atomized alloy tool steel powders.

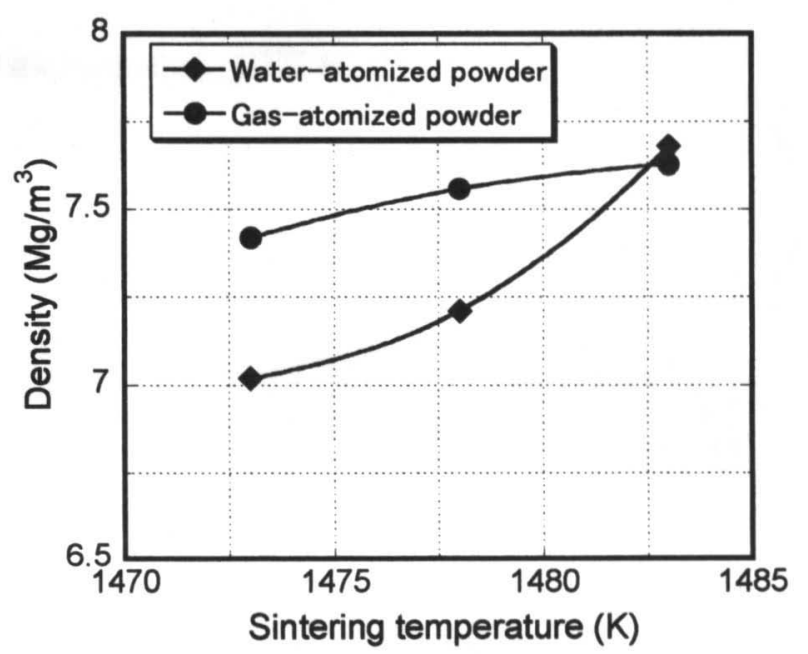

Fig.2 Effect of sintering temperature on the density of sintered compacts. 
度1483Kで焼結した焼結体の密度はほぼ真密度に匹敵する値 を示している.このように合金工具鋼の密度および組織は焼 結温度に対し非常に敏感であるため, 焼結温度を正確に制御 することが重要である.

\section{2 粉末特性の影響}

一般的に合金工具鋼は適切な熱処理を施し使用する鋼種で ある. Fig.4に焼もどし温度に対する水アトマイズ粉末とガス アトマイズ粉末を用いた焼結体の組織変化を示す. Fig.5に焼

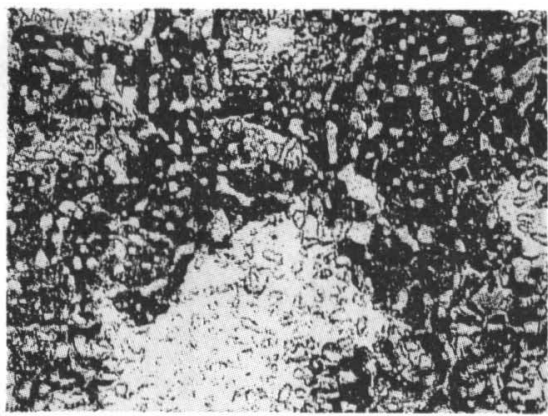

$1473 \mathrm{~K}$

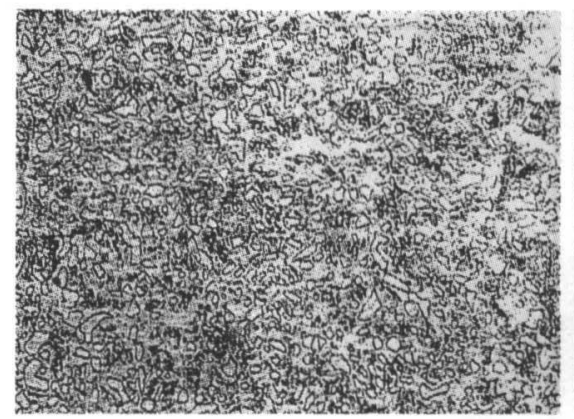

$1473 \mathrm{~K}$

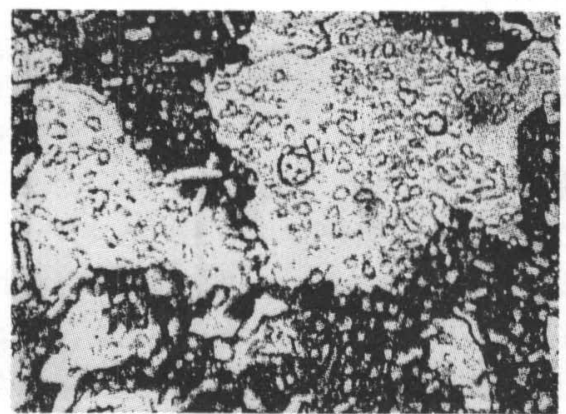

$1478 \mathrm{~K}$

(a) as'sintered

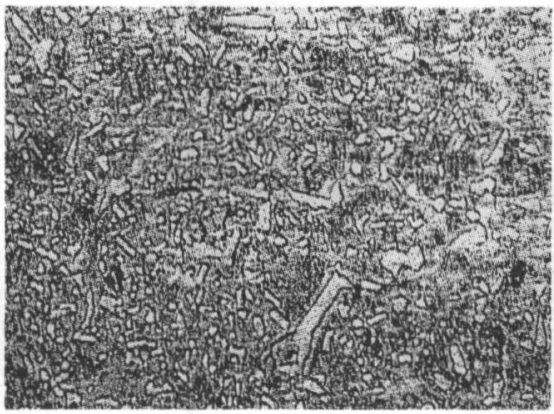

(b) annealed

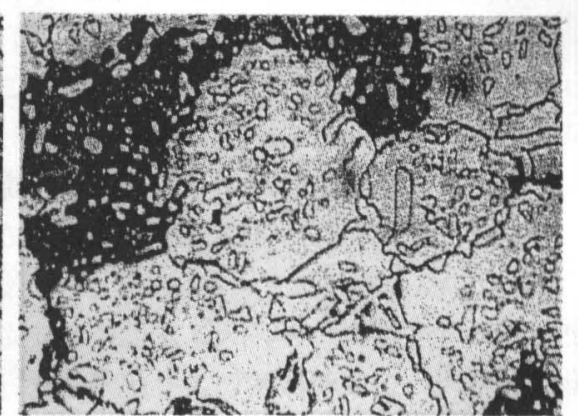

$1483 \mathrm{~K}$

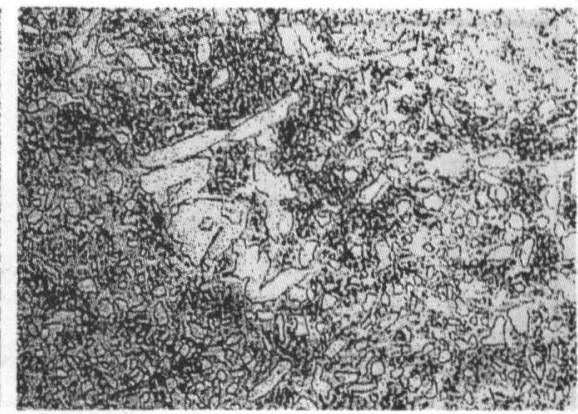

$1483 \mathrm{~K}$

Fig.3 Microstructures of as-sintered compacts and annealed compacts of gas-atomized powder.

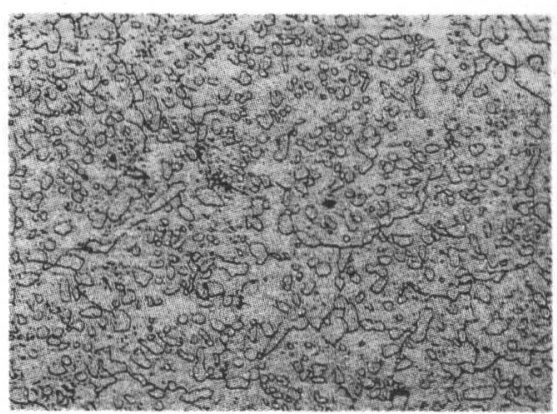

$453 \mathrm{~K}$

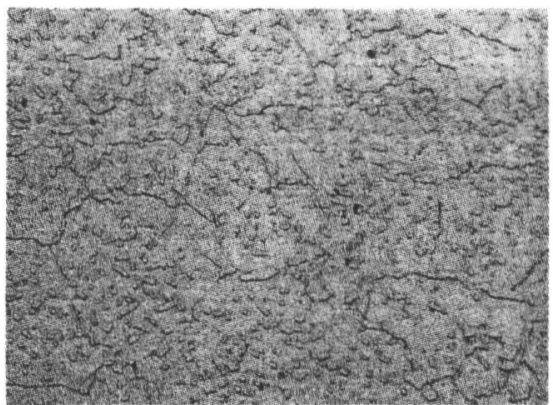

$453 \mathrm{~K}$

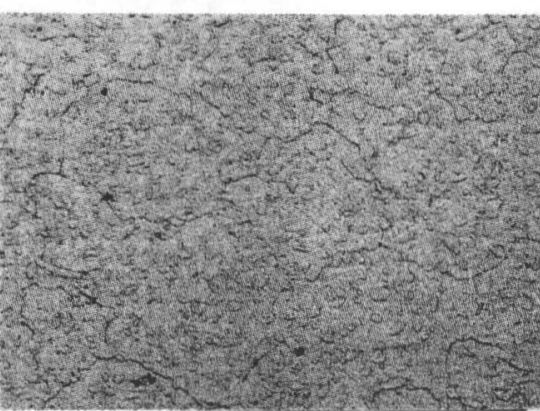

$543 \mathrm{~K}$

(a) GA powder

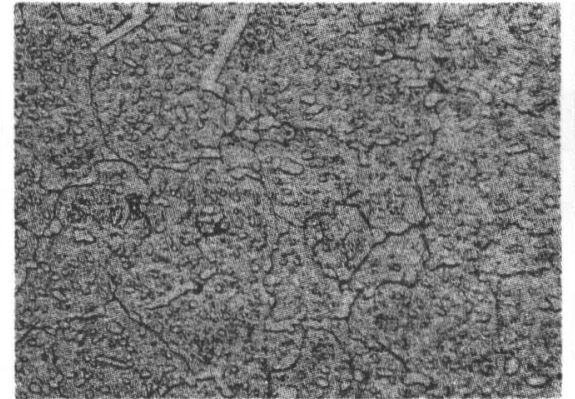

$543 \mathrm{~K}$

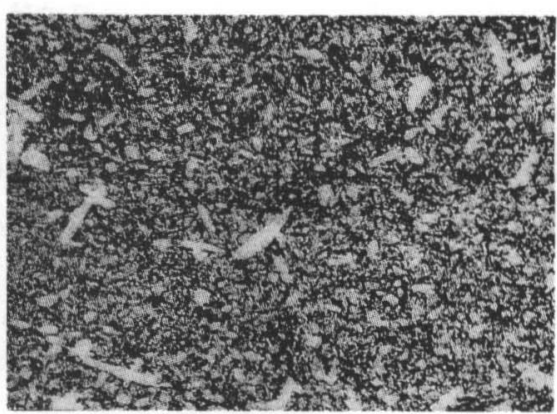

$803 \mathrm{~K}$

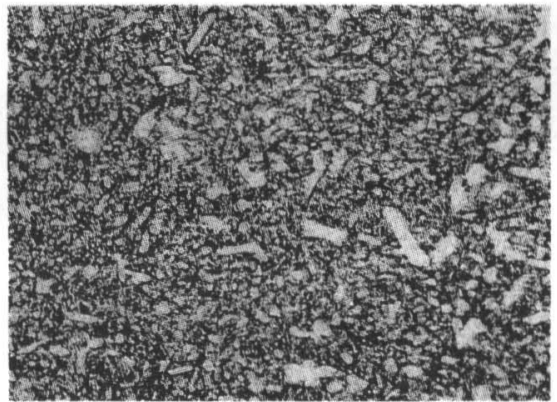

$803 \mathrm{~K}$

(b) WA powder

$20 \mu \mathrm{m}$

Fig.4 Variations in microstructures of the gas-atomized powder and water-atomized powder compacts as a function of tempering temperature. 
もどし温度 $453 \mathrm{~K}$ のガスアトマイズ粉末焼結体のSEM 観察お よびEDX分析結果を示す. 結晶粒界に形成した角張った粗い 炭化物 $\mathrm{M}_{7} \mathrm{C}_{3}$ と均一に分布した微細な球状炭化物 $\mathrm{M}_{23} \mathrm{C}_{6}$ が観察 され, EDX 分析の結果からこれらの炭化物では $\mathrm{Cr}, \mathrm{Fe}$ および Cで形成されている. Fig.4に示すように，両粉末焼結体とも， マトリックス組織は焼戻し温度の上昇に伴って大きく変化し ている.また, 炭化物についてみると, 炭化物 $\mathrm{M}_{7} \mathrm{C}_{3}$ の量はほ とんど変化しないが, $803 \mathrm{~K}$ の焼戻し温度では炭化物 $\mathrm{M}_{23} \mathrm{C}_{6}$ の 量は減少している.焼結のみの焼結体の炭化物 $\mathrm{M}_{7} \mathrm{C}_{3}$ は溶製材 の炭化物 $\mathrm{M}_{7} \mathrm{C}_{3}$ より小さいために, 焼もどしを施した焼結体の 炭化物 $\mathrm{M}_{7} \mathrm{C}_{3}$ も溶製材の炭化物 $\mathrm{M}_{7} \mathrm{C}_{3}$ より小さくなっている.

焼もどし温度に対する焼結体の硬さの変化を Fig.6に示す. 焼もどしした焼結体の硬さは焼結温度により影響され，焼結 温度が高いほど焼もどしした焼結体の硬さは高くなっている. 焼結温度に対するガスアトマイズ粉末焼結体の硬さの変化は, 水アトマイズ粉末焼結体の硬さの変化より小さい. ガスアト マイズ粉末焼結体の硬さはすべての焼もどし温度でHRC55よ り高い値を示している.これに対して，水アトマイズ粉末焼 結体の硬さは焼結温度 $1473 \mathrm{~K}$ と $1478 \mathrm{~K}$ では HRC55 より低い 値になり, 焼結温度 1483 Kのみで HRC55より高い值を示して いる.これはFig.2の密度の変化によく対応している. ガスア トマイズ粉末焼結体の硬さは焼もどし温度の上昇に伴い低下 する傾向を示している．これは焼もどし温度に対するマト

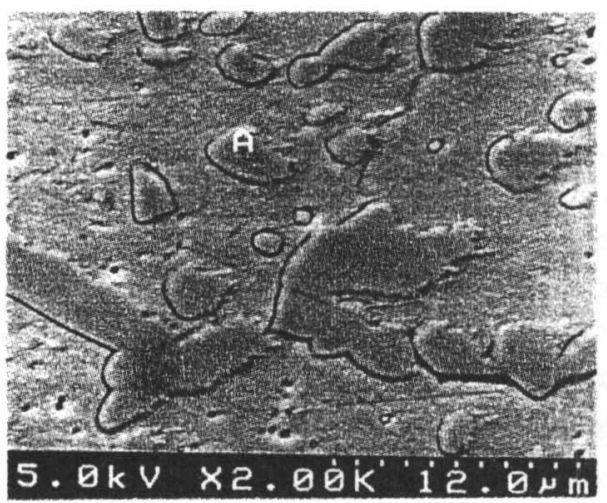

(a) SEM

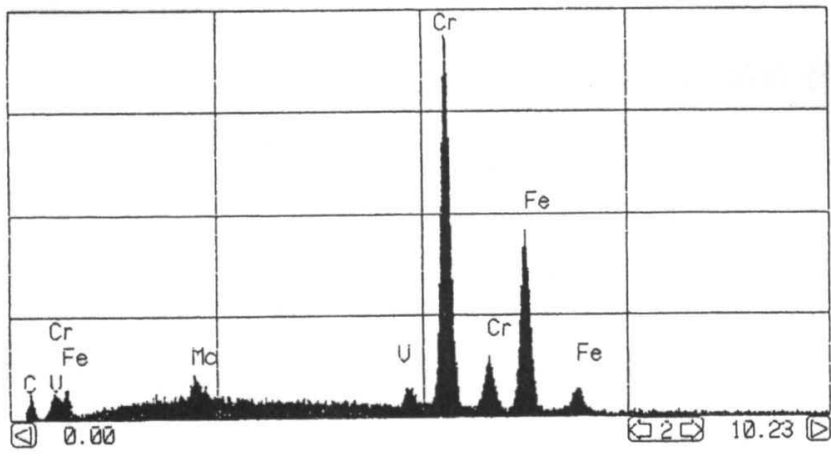

(b) EDX analysis

Fig.5 SEM image and EDX analysis of the sintered gas-atomized compact.
リックス組織および炭化物の変化に対応している. ガスアト マイズ粉末焼結体では焼もどし温度 $453 \mathrm{~K} て ゙ ~ H R C 58$ 以上の硬 さを示している.この值は溶製材に匹敵する值である.また， 水アトマイズ粉末焼結体も焼結温度 1483 KでHRC58以上の値 を示している.このように，焼結温度を制御することにより 優れた硬さを有する合金工具鋼を作製することができた.

焼もどし温度に対する焼結体の抗折力の変化を Fig.7に示 す. 焼もどし温度は焼結体の抗折力に大きな影響を及ぼして おり, また焼結温度も焼結体の抗折力に大きな影響を及ぼし ている. ガスアトマイズ粉末焼結体の抗折力はすべての焼結 温度で $3000 \mathrm{MPa}$ 以上の值を示しており, 水アトマイズ粉末焼 結体の抗折力より約 $500 \mathrm{MPa}$ 高い值を示している.これは Fig.2の変化とよく対応し, 焼結体の緻密化の影響を大きく受 けているためと考えられる. $1483 \mathrm{~K} て ゙$ 焼結したガスアトマイ ズ粉末焼結体の抗折力は焼もどし温度 $543 \mathrm{~K}$ と $803 \mathrm{~K}$ の場合に は焼結温度 $1473 \mathrm{~K}$ と $1478 \mathrm{~K}$ の焼結体より低い值になった.こ れは, 焼もどし後にも結晶粒界に沿って形成した角張った粗い 炭化物 $\mathrm{M}_{7} \mathrm{C}_{3}$ が残留するためと考えられる. Fig. 8 に示す $453 \mathrm{~K}$ で焼もどししたガスアトマイズ粉末焼結体の抗折試験後の破 面には炭化物 $\mathrm{M}_{7} \mathrm{C}_{3}(\mathrm{~A})$ の脆性破面が観察される.このように，

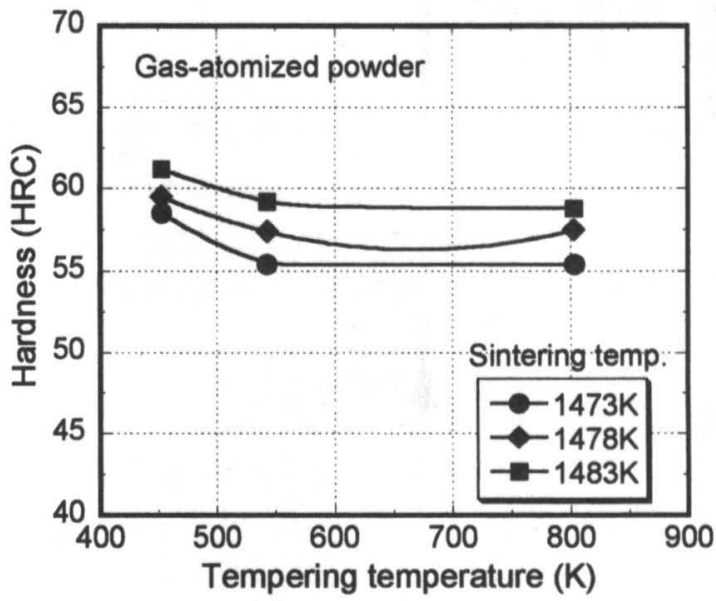

(a) GA powder

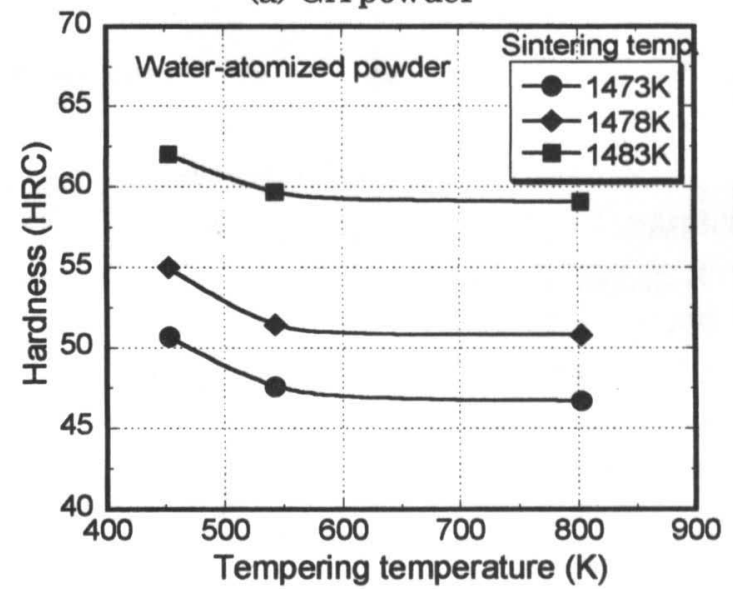

(b) WA powder

Fig.6 Effect of tempering temperature on the hardness of sintered compacts. 


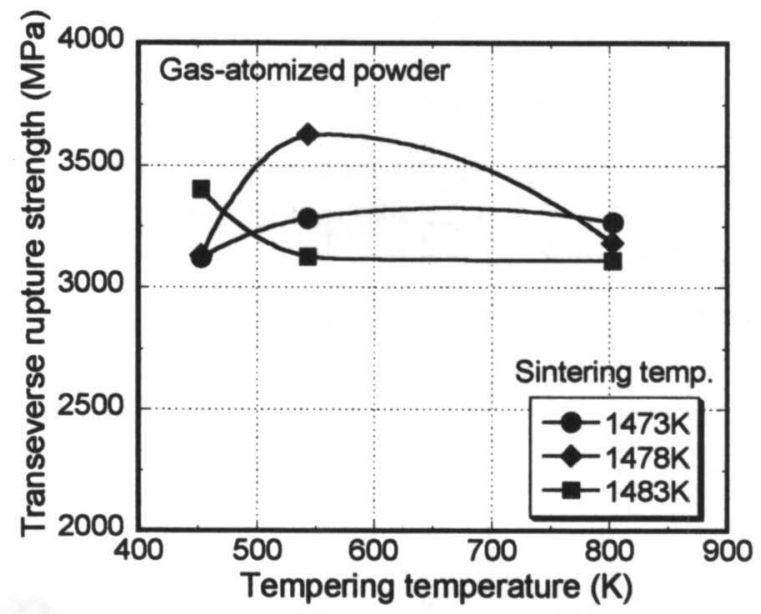

(a) GA powder

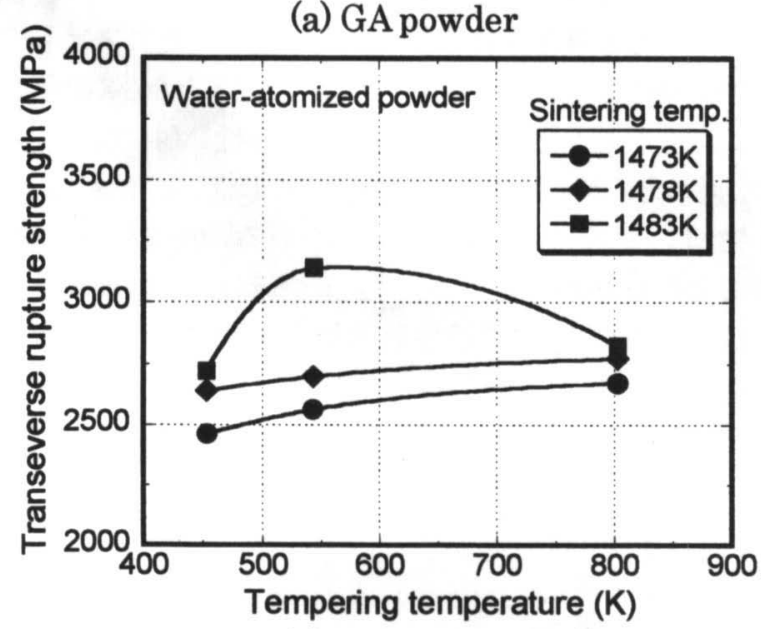

(b) WA powder

Fig.7 Effect of tempering temperature on the transverse rupture strength of sintered compacts.

$\mathrm{M}_{7} \mathrm{C}_{3}$ 炭化物の形成は硬さを向上させるが抗折力は低下させ る.いずれにしても, 炭化物の形状や大きさ，分布状態が機 械的性質に影響を及ぼすため, 狫結条件および熱処理条件に ついては十分注意する必要がある.

\section{4 結 言}

本研究では, 合金工具鋼 (SKD11)のガスアトマイズ粉末と 水アトマイズ粉末を用いて, 粉末特性が射出成形による焼結 体の組織および機械的性質に及ぼす影響について検討した。 得られた結果は次のとおりである.

(1) ガスアトマイズ粉末焼結体の方が水アトマイズ粉末焼結体 より低い温度で緻密化した。

(2) 硬さは焼もどし温度の上昇に伴って低下し,焼もどし温度 $543 \mathrm{~K}$ ではガスアトマイズ粉末焼結体では溶製材の JIS 規 格 HRC58 以上の值を示した.

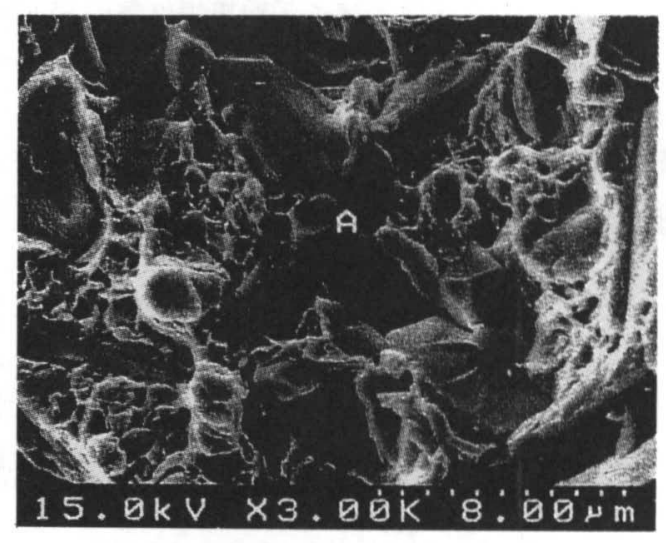

Fig.8 Fractured surface of the gas-atomized compact tempered at $453 \mathrm{~K}$.

(3) ガスアトマイズ粉末焼結体の抗折力はすべての焼もどし温 度で $3000 \mathrm{MPa}$ 以上の值を示し, 水アトマイス粉末の抗折 カより約 500MPa 高い值を示した.

（4）焼結条件や熱処理条件をコントロールすることにより溶製 材に匹敵する機械的性質を有する合金工具鋼(SKD11)を作 製することができた.

\section{文献}

1) 三浦秀士, 権藤寛, 河野富夫, 本田忠敏: "金属粉末射出成 形法による高速度鋼の作製 ", 粉体および粉末治金, 40 (1993)393-396.

2) 櫻木進, 佐々木卓也, 山田豊, 石原守, 中山譲: " 高速度鋼 射出成形体の強度特性 ", 粉体および粉末治金, 40(1993) 1242-1245.

3) H.Miura and T.Hondo: "Properties of High Speed Steel MIM Parts Produced by Different Types of Powders", Proceedings of PM '94, Powder Metallurgy World Congress, Shrewsbury, European Powder Metallurgy Association, (1994)1129-1132.

4) I.H.Moon, S.H.Lee and M.J.Suk: "Metal Injection Molding of the Powder Mixture Equivalent to M2 High Speed Steel", Advanced in Powder Metallurgy \& Particulate Materials-1995, Vol.2, compiled by M.Phillips, J. Porter, Metal Powder Industries Federation, Princeton, NJ, (1995)6.79-6.87.

5) R.M.German and A.Bose: Injection Molding of Metals and Ceramics, Metal Powder Industries Federation, Princeton, NJ, (1997)261.

6) 中山英樹, 山上勝義, 京極秀樹, 小松眞一郎 : "金属粉末射 出成形法による SUS304L焼結体の機械的性質に及ぼす粉 末特性の影響 ",粉体および粉末冶金, 44(1997)427-431.

7) (財) 素形材センター編 : 素形材の組織, 日刊工業新聞社, (1988)180. 